\title{
A pseudoscorpion species new to Finland and an updated checklist (Arachnida: Pseudoscorpiones)
}

\author{
Новый виА можноскорпиона Аля фауны Финляндии \\ и обновлённый список видов (Arachnida: Pseudoscorpiones)
}

\author{
Annika Uddström ${ }^{1} \&$ Veikko Rinne ${ }^{2}$ \\ А. УАдстрём ${ }^{1}$, В. Ринне ${ }^{2}$ \\ ${ }^{1}$ Finnish Environment Institute, Natural Environment Centre, P.O. Box 140, FI-00260 Helsinki, Finland. E-mail: \\ annika.uddstrom@ymparisto.fi \\ ${ }^{2}$ Zoological Museum, University of Turku, FI-20014 Turku, Finland. E-mail: veikko.rinne@utu.fi \\ KEY WORDS: False scorpions, new record, northern Europe. \\ КЛЮЧЕВЫЕ СЛОВА: ложноскорпионы, новая находка, Северная Европа.
}

ABSTRACT. Microbisium suecicum Lohmander, 1945 is reported from Finland for the first time. The characters that distinguish it from the closely related M. brevifemoratum (Ellingsen, 1903) are given. A checklist of the 17 species of Finnish pseudoscorpions is presented. A brief history of research on pseudoscorpions in Finland is also presented.

РЕЗЮМЕ. Впервые для фауны Финляндии отмечен ложноскорпион Microbisium suecicum Lohmander, 1945. Указаны его отличия от близкого $M$. brevifemoratum (Ellingsen, 1903). Приведен список ложноскорпионов зарегистрированных в Финляндии. Приведён краткий исторический обзор изучения группы в стране.

\section{Introduction}

There has been little research on pseudoscorpions in Finland [see Koponen, 2011]. The first list of species, with an identification key, was provided by Väänänen [1928], but only in Finnish. He reported six species. Kaisila [1949] reviewed the pseudoscorpion fauna of Eastern Fennoscandia, including 16 species from Finland. His detailed work was based on many museum samples. Lagerspetz [1953] made an ecological study on a community of Dactylochelifer latreillei (Leach, 1817) on seashore rocks, and Lehtinen [1964] commented on four species at their northern limits in Finland. Later, some scattered information about pseudoscorpion species has been included in ecological reports on local arthropod faunas.

Finnish pseudoscorpions have recently been studied as a part of the research programme of deficiently known and threatened forest species (PUTTE). When the three-year project "Identification guide of Finnish Opiliones and Pseudoscorpiones" started in 2012, there were 16 pseudoscorpion species reported from Finland [Kaisila, 1949; Harvey, 2013]. So far it seems that the Finnish pseudoscorpion fauna has not undergone as a dramatic change as the opilionid fauna during the last decades. The number of opilionid species known from Finland has increased by four species [Uddström et al., 2013]. Here we present one pseudoscorpion species new to Finland, along with the main characteristics for the identification of this species. We also present an updated checklist of Finnish pseudoscorpions.

\section{Material and methods}

The habitus photograph was taken using an Olympus Camedia E-520 camera attached to an Olympus SZX16 stereomicroscope and that of the pedipalpal chela with an Olympus Camedia C-5050 Zoom camera attached to an Olympus BH-2 microscope, both at the Zoological Museum, University of Turku. Digital images were prepared using "CombineZP" image stacking software. The single specimen of Microbisium suecicum studied is from the Zoological Museum, University of Helsinki, as is also the specimen of M. brevifemoratum (Ellingsen, 1903) (FINLAND, Pieksämäki, 25.6. 1936, L. Siivonen leg., MZH No 112.284).

\section{Species new to Finland}

\section{Microbisium suecicum Lohmander, 1945}

Figs 1, 2B.

MATERIAL EXAMINED: FINLAND, Åland Islands, Lemland, Apalholmen, forest litter, 9.05.1954, 1 specimen, leg. \& det. Jouko Kaisila, MZH No 112.278.

COMMENTS. This specimen (Fig. 1) of M. suecicum was found in the collections of the Zoological Museum of the Finnish Museum of Natural History, Helsinki. The collecting locality lies on the Alland Islands, the southwesternmost corner of Finland. We have not been able to find any other specimens of this species.

Microbisium suecicum (Fig. 1) is a relatively small species with two pairs of eyes and a glossy cuticular 


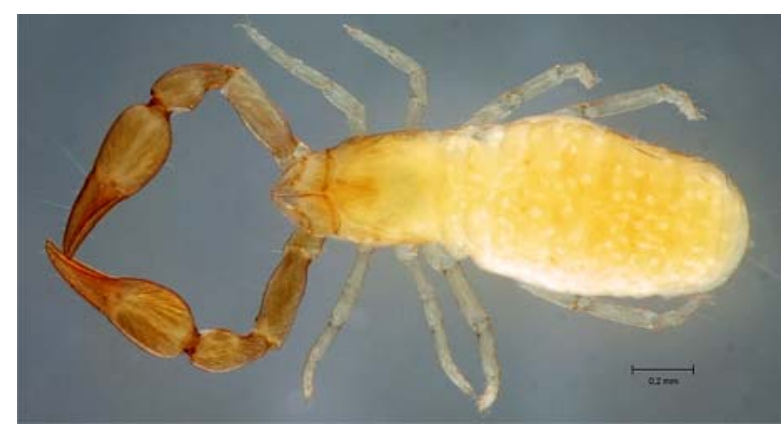

Fig. 1. Habitus of Microbisium suecicum, dorsal view.

Рис. 1. Внешний вид Microbisium suecicum, досально.

surface. M. suecicum differs from the sibling $M$. brevifemoratum by being smaller $(1.4-1.8 \mathrm{~mm}, \mathrm{M}$. brevifemoratum is $1.6-2.4 \mathrm{~mm}$ ), the carapace as long as wide (slightly longer than wide in $M$. brevifemoratum) and both relatively and absolutely shorter pedipalpal fingers. M. suecicum has only 26-28 teeth on the fixed finger (Fig. 2B), while M. brevifemoratum has 40-42 teeth (Fig. 2A). In addition, M. suecicum has no colour contrast between the tergites and the soft intersegmental membrane [Gärdenfors \& Wilander, 1992].

BIOLOGY. The species occurs in open forests, in forest litter and moss [Gärdenfors \& Wilander, 1992], while the related species $M$. brevifemoratum occurs mainly in peatlands [Kaisila, 1949; Lehtinen, 1964]. In Sweden, many of the observations of $M$. suecicum are from boulder fields [Sandström, 2007]. The only specimen known from Finland was found in forest litter at the base of a rock wall. The species also occurs in Central and Southern Europe and Morocco; for general distribution see Harvey [2013].

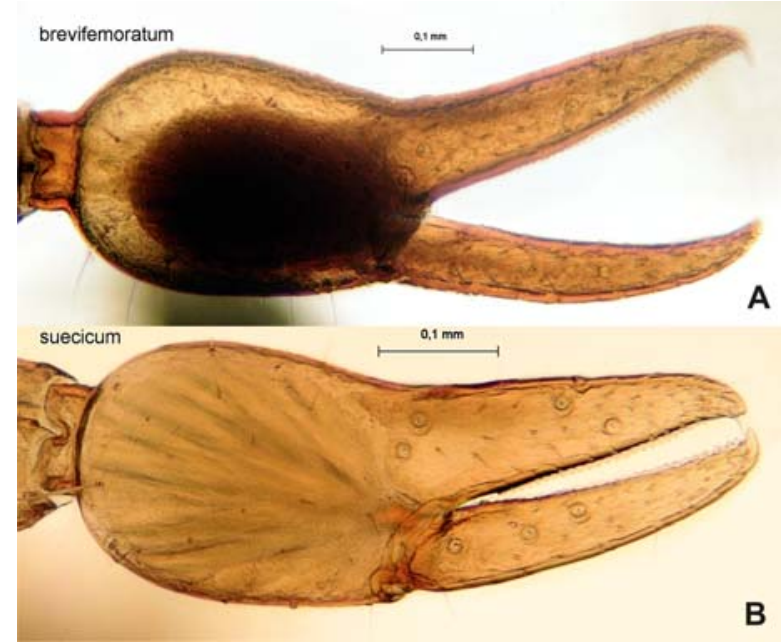

Fig. 2. Pedipalpal chela of Microbisium brevifemoratum (A) and M. suecicum (B).

Note: Microbisium suecicum has shorter pedipalpal fingers than $M$. brevifemoratum, and less than 30 teeth in the fixed finger.

Рис. 2. Клешня педипальп Microbisium brevifemoratum (А) и $M$. suecicum $(\mathrm{B})$

Примечание: У M. suecicum палец педипальпы короче чем у $M$. brevifemoratum, и имеет менее 30 зубчиков на неподвижном пальце.

\section{Checklist of Finnish pseudoscorpions}

Chthoniidae Chthoniinae

Chthonius tetrachelatus (Preyssler, 1790)

Neobisiidae

Neobisiinae

Microbisium brevifemoratum (Ellingsen, 1903)

Microbisium suecicum Lohmander, 1945

Neobisium carcinoides (Hermann, 1804)

Cheiridiidae

Cheiridiinae

Apocheiridium rossicum Redikorzev, 1935

Cheiridium museorum (Leach, 1817)

Cheliferidae

Cheliferinae

Chelifer cancroides (Linnaeus, 1758)

Dactylochelifer latreillii (Leach, 1817)

Chernetidae

Chernetinae

Chernes cimicoides (Fabricius, 1793)

Chernes nigrimanus Ellingsen, 1897

Dendrochernes cyrneus (L. Koch, 1873

Dinocheirus panzeri (C.L. Koch, 1837) Lamprochernetinae

Allochernes wideri (C.L. Koch, 1843)

Lamprochernes chyzeri (Tömösváry, 1882)

Lamprochernes nodosus (Schrank, 1803)

Pselaphochernes dubius (O. Pickard-Cambridge, 1892)

Pselaphochernes scorpioides (Hermann, 1804)

ACKNOWLEDGEMENTS. We are grateful to Seppo Koponen for valuable comments on an earlier version of the article and to Mark Harvey for reviewing the manuscript. David Penney (Manchester) checked the language of the final draft.

\section{References}

Harvey M. 2013. Pseudoscorpions of the World, version 3.0. http:// museum.wa.gov.au/catalogues-beta/pseudoscorpions [last accessed 12.02.2014]

Gärdenfors U., Wilander P. 1992. Sveriges klokrypare med nyckel till arterna // Entomologiskt Tidskrift. Nr.113. P.20-35.

Kaisila J. 1949. A revision of the Pseudoscorpion fauna Eastern Fennoscandia // Annales Entomologici Fennici. Vol.15. No.1. P.72-92.

Koponen S. 2011. Arachnology in Finland 2 // Memoranda Soc. Fauna et Flora Fennica. Vol.87. P.87-94.

Lagerspetz K. 1953. Biocoenological notes on the Parmelia saxatilis - Dactylochelifer latreillei community of seashore rocks // Archivum Societatis Zoologicae Botanicae Fennicae 'Vanamo'. Vol.3. P.131-142.

Lehtinen P.T. 1964. The Phalangids and Pseudoscorpionids of Finnish Lapland // Reports from the Kevo Subarctic Research Station. Vol.1. P.279-287.

Sandström J. 2007. Microbisium suecicum - skogsklokrypare. Artdatabanken. http://www.artfakta.se/SpeciesFact.aspx?TaxonId $=102560$ [last accessed 23.01.2014]

Uddström A., Rinne V., Pajunen T. 2013. Opiliones new to Finland and an updated checklist // Memoranda Soc. Fauna et Flora Fennica. Vol.89. P.1-3.

Väänänen H. 1928. Suomen valeskorppioonilajit // Luonnon Ystävä. Vol.32. P.9-19. 